\title{
Effects of shellfish farming on the benthic environment
}

\author{
Christine M. Crawford*, Catriona K.A. Macleod, Iona M. Mitchell \\ Tasmanian Aquaculture and Fisheries Institute, University of Tasmania, Nubeena Crescent, Taroona, Hobart, \\ Tasmania 7053, Australia
}

Received 4 October 2002; received in revised form 13 February 2003; accepted 18 February 2003

\begin{abstract}
The benthic environment under and near three shellfish farms in Tasmania, Australia, which had had a relatively high level of production over many years was investigated. Benthic samples were collected along transects which ran across the farms, generally from $100 \mathrm{~m}$ upstream to $100 \mathrm{~m}$ downstream. Sediment deposition, redox values, sediment sulphide concentrations, organic carbon content and water turbidity levels near the bottom were significantly different between the farms but not between sites outside the farm, at the boundary and sites within the farm. Video recordings at one farm showed dense coverage of fine filamentous algae and patchy bacterial mats directly under some longlines and this algae is thought to have fallen off the mussel longlines. At another farm dense beds of seagrass were observed in the videos both under trays of oysters and outside the farm. The benthic infauna did not show clear signs of organic enrichment, and neither univariate nor multivariate measures of benthic infauna were significantly different between sites inside and outside the farm, although they were different between farms.

It was concluded from these results that shellfish farming is having little impact, and much less than salmon farming, on the benthic environment in Tasmania. Thus extensive monitoring of shellfish farms would appear to be not necessary.
\end{abstract}

(C) 2003 Elsevier Science B.V. All rights reserved.

Keywords: Shellfish farming; Environmental impact; Benthic environment

\section{Introduction}

Literature reports indicate a variety of levels of effect of shellfish farming activities on the benthic marine environment. These range from significant impact such as

\footnotetext{
* Corresponding author. Tel.: +61-3-62277224; fax: +61-3-62278035.
}

E-mail address: Christine.Crawford@utas.edu.au (C.M. Crawford). 
extensive bacterial mats underneath mussel longlines (Dahlbäck and Gunnarsson, 1981) and changes in benthic community composition under shellfish culture structures (Tenore et al., 1982) to minimal effects (e.g. Baudinet et al., 1990; Buschmann et al., 1996). Most studies on organic enrichment of the seabed from shellfish farming have concluded that the effect is small, and much less than that caused by finfish farming. Details of environmental impacts of bivalve mariculture on the environment are given in reviews by Kaiser et al. (1998) and Kaiser (2000). Kaiser et al. (1998) concluded that environmental changes as a result of shellfish farming can be minimised by using appropriate culture techniques.

In Tasmania, Australia, commercial farming of shellfish is an important and expanding rural industry. The principle species grown is the Pacific oyster, Crassostrea gigas (Thunburg, 1793), which was introduced into Tasmania from Japan in the late 1940s and early 1950s (Thomson, 1952). Small quantities of the native blue mussel, Mytlis planulatis (Linnaeus, 1758) are also cultured. Production of Pacific oysters in 1997/1998 was 2065 tonnes, and valued at US\$6.2 million. Mussel production over the same time period was 343 tonnes, with an estimated gross vale of US\$382000 (DPIWE, 1999a). In 1995, 1351 ha were available for farming, and recently an additional 700 ha has become available, mostly in subtidal waters. Pacific oyster farming is predicted to significantly increase over the next few years, and is expected to contribute in the order of US\$20-30 million per annum to the Tasmanian economy by 2005 , and to employ $400-500$ people full time (DPIWE, 1999a). The mussel culture industry has also been identified as having potential for major expansion to 1500 tonnes per annum in the next few years (DPIWE, 1999b).

However, in contrast to the proactive view of industry and government for the development of shellfish aquaculture in Tasmania, there is increasing community concern about the effects that shellfish farming may be having on the environment. Sections of the community have vigorously opposed expansion of shellfish farms in many bays and estuaries around Tasmania. This has occurred even though the densities of shellfish on the farms are much lower than in many other countries and Tasmanian farming techniques of intertidal off-bottom rack culture or suspended from longlines in deep water are less damaging to the environment than some practises used elsewhere such as cultivation directly on the bottom and harvesting by dredging.

This project was developed to provide accurate information on the effects of shellfish farming on the Tasmanian environment. The objectives were twofold:

- To quantify the effects of shellfish farming on the benthic environment from a study of the environment around several long established farms.

- To provide the scientific information from which practical, quantitative and costeffective methods for sustainable management of shellfish farming can be developed.

\section{Methods}

Three existing farms in eastern and southeastern Tasmania which have had a relatively high level of production over many years were investigated. However, only subtidal oyster 
and mussel farms were examined because in these systems shellfish are grown throughout the water column on longlines and a higher density of shellfish per area of seabed can be achieved than on intertidal farms. These farms, therefore, have the potential to cause greater change to the benthic environment than intertidal farms. The benthic invertebrate community and environmental conditions at intertidal farms in Tasmania has already been investigated by Thorne (1998).

\subsection{Sampling protocol}

Environmental data were collected in January and February 2000, during the warmer months of the year when impacts are likely to be greater. Three long transects were located across each farm, from $100 \mathrm{~m}$ upstream to $100 \mathrm{~m}$ downstream and running parallel with the current, to investigate whether there was a gradient in environmental conditions from areas of intensive farming activity to areas further away from the farm. Ideally, nine sample sites were allocated along these transects: at the centre of farm (or centre of major farming activity), midway between centre and farm boundary, at the boundary, $50 \mathrm{~m}$ from the boundary, and $100 \mathrm{~m}$ from the boundary. However, some modifications to this design were required at each farm because of site-specific characteristics and the size and shape of farms.

\subsection{Sample sites}

The farm investigated at Port Esperance has been used for farming oysters and mussels since 1984 and has an area of 5.6 ha. It is in depths of 8-12 $\mathrm{m}$ and preliminary current data indicate that the predominant direction of water flow is in a northwestern direction, parallel to the shoreline. Three transects were allocated across the farm parallel to the direction of flow and alignment of the longlines, as shown in Fig. 1. Samples were not collected at $100 \mathrm{~m}$ upstream. Production of shellfish, mainly Pacific oysters, from this farm has averaged 108 tonnes per annum over the last 10 years.

The second farm at St. Helens was granted in 1991 for an area of 3 ha and by 1998 the lease was fully developed with mussels and oysters. It was expanded to 6 ha in 1999 and the new lease area was under development at the time of this study. Water temperatures in the area have an annual range of $7-20^{\circ} \mathrm{C}$, and salinity ranges from 5.6 to $35.3 \mathrm{psu}$ (DPIWE, 1998). Water depths in the lease area ranged from 7.5 to $9 \mathrm{~m}$, with a deeper channel to the south of the farm. The average current flow near the farm at 2-6 $\mathrm{m}$ above the seabed was $3.8 \mathrm{~cm} \mathrm{~s}^{-1}$. A higher average flow of 18.5 $\mathrm{cm} \mathrm{s}^{-1}$ was recorded in the upper water column and was thought to have been due to wind influence. The three transects across this farm were located on the existing lease area (Fig. 2), and were parallel with the alignment of the longlines. Sample sites off the northern upstream boundary were only 35 and $50 \mathrm{~m}$ from the boundary because of the close proximity of another shellfish farm. Production of oysters and mussels from this farm over 7 years has averaged 73 tonnes per annum.

The third farm at Eaglehawk Bay was 13.8 ha in size and commenced operation in the late $1970 \mathrm{~s}$, farming mostly oysters and some mussels. The annual range in water temperature averaged $9-21^{\circ} \mathrm{C}$, and salinity $31-33 \mathrm{psu}$ (DPIF, 1996). This lease was 


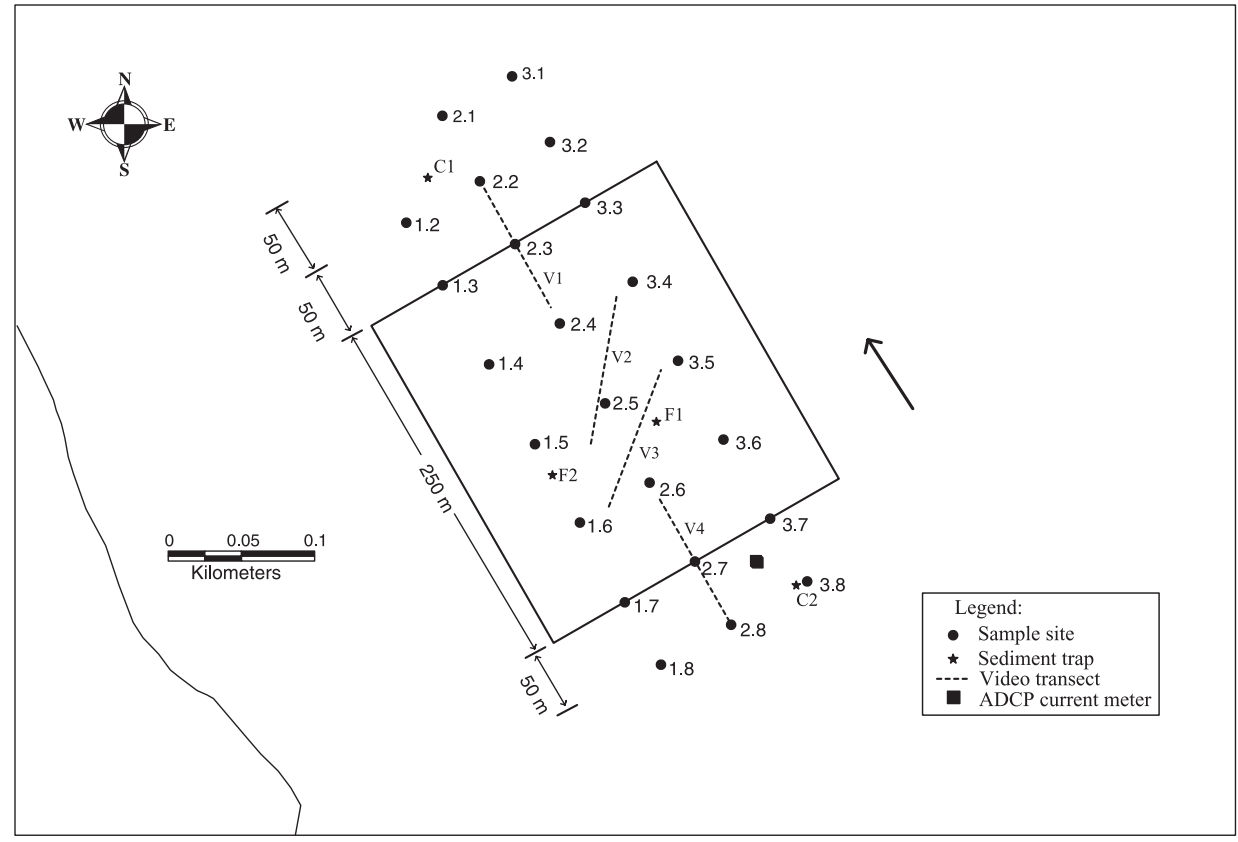

Fig. 1. Port Esperance marine farm. Arrow indicates approximate direction of current flow.

partially relocated further off shore in 1999-2000. Current speed midwater, measured over 12.5 days at $4-8 \mathrm{~m}$ above the seabed, averaged $3.4 \mathrm{~cm} \mathrm{~s}^{-1}$, with $99.7 \%$ of flow less than $10 \mathrm{~cm} \mathrm{~s}^{-1}$. The predominant direction of flow was in a E/NE direction, parallel to the shoreline. Our study area was located in the original lease area, which had been farmed for the longest period of time (Fig. 3). However, locating transects across the farm was difficult because of the shape of the farm, shallow depths on three boundaries and expansion of the lease area further out into the bay. Most of the farm was in depths of $8-10 \mathrm{~m}$, although it shallowed to $4 \mathrm{~m}$ on the northern side and rapidly decreased in depth on the eastern and western boundaries. Thus sample sites on the eastern boundary are close together. Transects were perpendicular to the alignment of longlines and approximately parallel to the direction of current flow. Production of oysters from this farm has averaged 220 tonnes per annum over the last 12 years.

\subsection{Environmental data}

At each sample site two cores were collected by divers using Perspex cores (50 $\mathrm{mm}$ diameter and $240 \mathrm{~mm}$ height). The colour and content of each core was described, and any flora and fauna present, gas bubbles and obvious smell $\left(\mathrm{H}_{2} \mathrm{~S}\right.$ odour) were recorded. The redox potential and sulphide content were measured at 1 and $4 \mathrm{~cm}$ depth in the core. Approximately $100 \mathrm{~g}$ of sediment was collected from the 


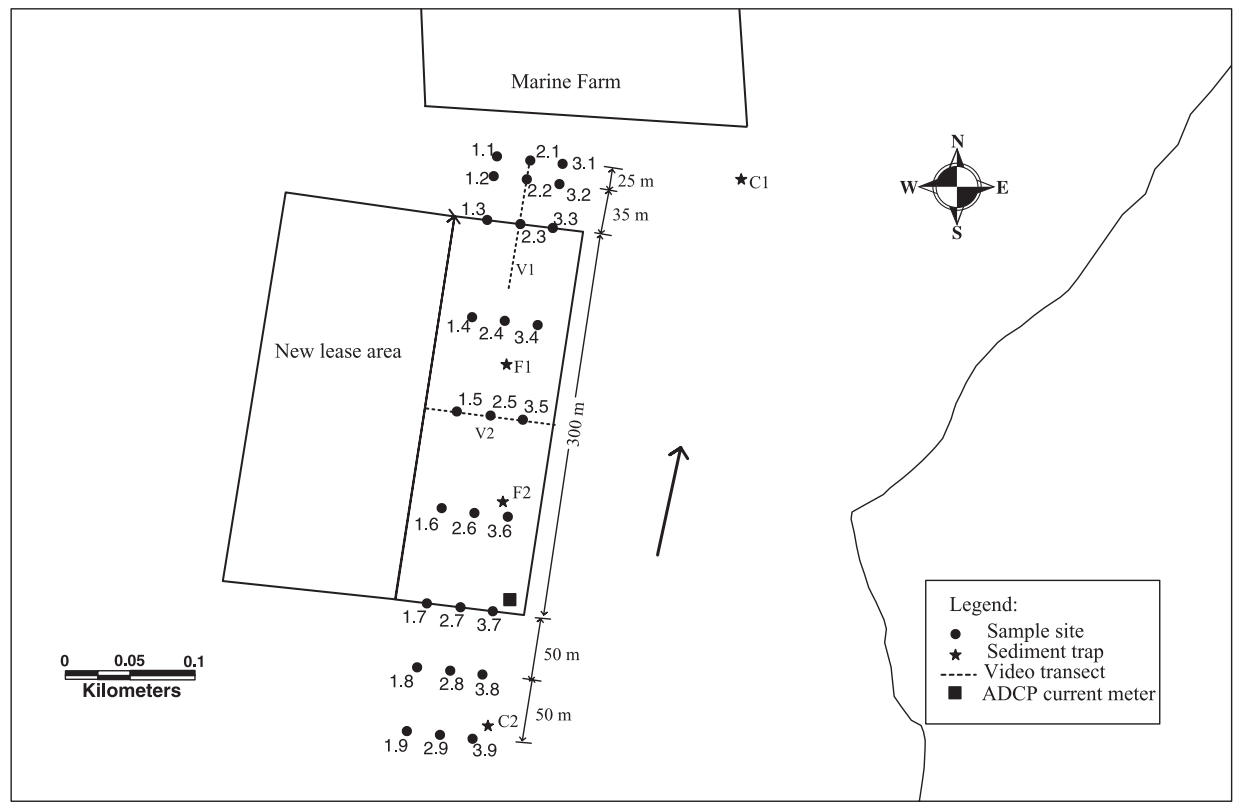

Fig. 2. Marine farm at St. Helens. Arrow indicates approximate direction of current flow.

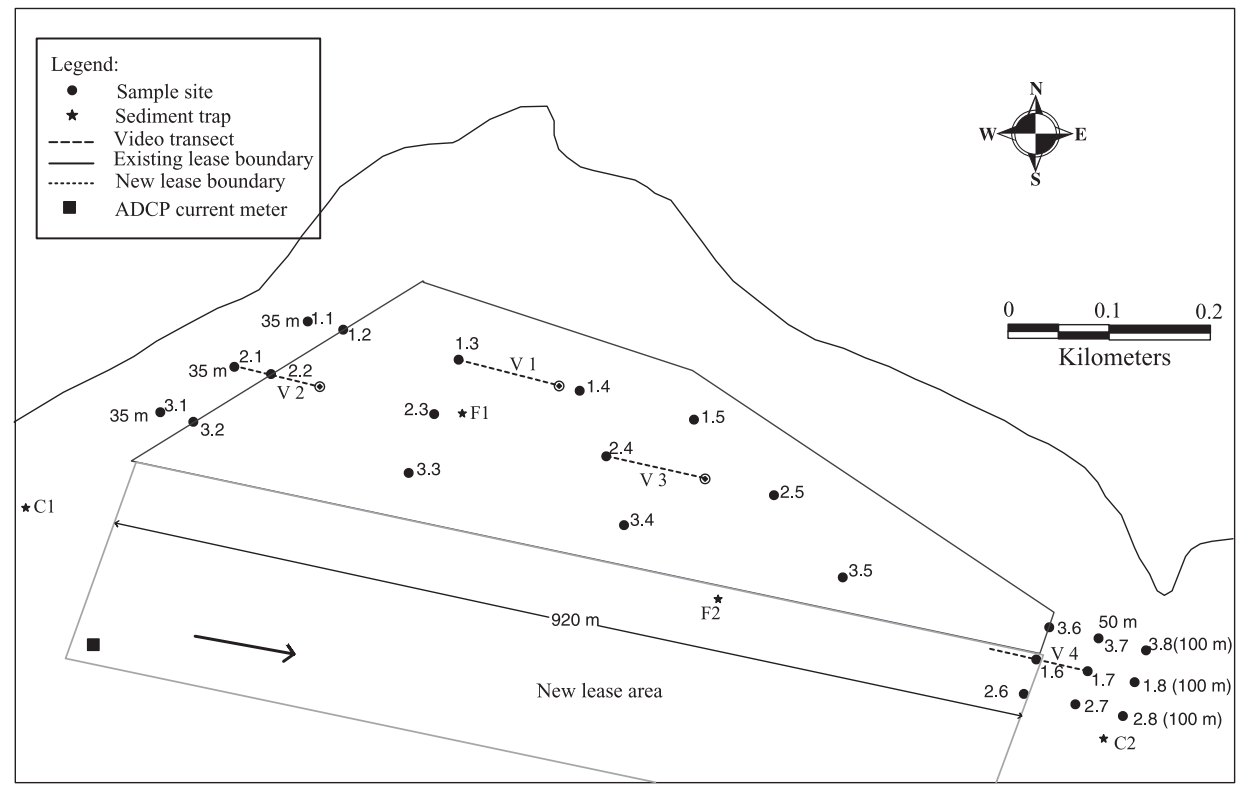

Fig. 3. Marine farm at Eaglehawk Bay. Arrow indicates approximate direction of current flow. 
top $2 \mathrm{~cm}$ of each core and frozen for later analysis of sediment particle size composition and organic carbon content.

Two sediment samples for benthic invertebrate faunal assessment were collected at each sample site using PVC pipe corers (diameter $150 \mathrm{~mm}$ ) to a depth of $100 \mathrm{~mm}$. The sediment was sieved through a $1-\mathrm{mm}$ sieve and all organisms retained were preserved in $4 \%$ buffered formalin. After sorting the macrofauna were transferred into $70 \%$ ethanol for longer-term storage. Infauna were identified to the lowest possible taxonomic order, species where possible, and enumerated.

At each sample site $500 \mathrm{ml}$ of seawater was collected at $2 \mathrm{~m}$ above the bottom using a Niskin sample bottle. On return to the laboratory, the turbidity was measured using a HACH 2100P Turbidimeter.

Video footage of the seabed was collected at each farm using a diver operated Hi-8 underwater video camera (Blaupunkt Video Camera Recorder Model CC984 (Hi-8 Pal) $10 \times$ zoom colour camera). Four transects, $100 \mathrm{~m}$ in length, were filmed at each farm. Two transects were located near the centre of the farm, and one at each upstream and downstream boundary, starting $50 \mathrm{~m}$ inside the boundary and extending to approximately $50 \mathrm{~m}$ beyond the boundary. The transects were marked every $10 \mathrm{~m}$ and were aligned perpendicular to the longlines. The video footage was collected and assessed according to the techniques of Crawford et al. (2001).

Four sediment traps were deployed at each farm for $2-3$ days. Two traps were located near the centre of the farm, and two outside the farm at approximately $50 \mathrm{~m}$ from the upstream and downstream farm boundaries. Each sediment trap consisted of three PVC cylinders ( $90 \mathrm{~mm}$ diameter $\times 520 \mathrm{~mm}$ height) attached approximately $75 \mathrm{~cm}$ from the base of a central metal frame (i.e. the traps were approximately $75 \mathrm{~cm}$ off the seabed). The sediment collected in the traps was allowed to settle over several days before siphoning off the supernatant water. It was oven dried at $110^{\circ} \mathrm{C}$ for $2 \mathrm{~h}$ and cooled in a dessicator before weighing.

\subsection{Physical and chemical analyses}

Particle size composition of sediment collected in cores was determined by passing oven dried and weighed sediment samples ( $100 \mathrm{~g})$ through 4-mm, 2-mm, 1-mm, 500$\mu \mathrm{m}, 250-\mu \mathrm{m}, 125-\mu \mathrm{m}$ and $63-\mu \mathrm{m}$ mesh sieves, and weighing the contents retained on each sieve and the remainder that passed through all sieves. Particle size composition of each sieve fraction was calculated as a percentage of the initial total weight.

Redox potential in core samples was measured using a Mettler Toledo $\mathrm{pH} /$ redox probe at 1 and $4 \mathrm{~cm}$ below the surface of the cores, using methods similar to those described by Wildish et al. (1999). The probe was calibrated using Zobells ferro/ferricyanide redox buffer solution and allowed to equilibrate for $10 \mathrm{~s}$ before taking each reading. Results were corrected to the standard hydrogen reference electrode.

Sulphide $\left(\mathrm{S}^{2-}\right)$ was measured using a Cole-Parmer silver/sulphide ion selective combination electrode according to the methods of Wildish et al. (1999). Prior to each sampling trip, the probe was calibrated using standards made from sodium sulphide $\left(\mathrm{Na}_{2} \mathrm{~S} \cdot 9 \mathrm{H}_{2} \mathrm{O}\right)$. Sediment samples were mixed immediately after collection with sulphide antioxidant buffer $(1: 1 \mathrm{v} / \mathrm{v})$. Sulphide levels were recorded in millivolts when the reading 
stabilised, or after a maximum of $90 \mathrm{~s}$. Results were converted to micromolar concentrations.

Organic carbon content of sediment samples was evaluated after the sediments were treated with sufficient $1 \mathrm{~N}$ hydrochloric acid $(\mathrm{HCl})$ to ensure complete dissolution of carbonaceous material. Following acidification, samples were oven dried at $50{ }^{\circ} \mathrm{C}$ overnight and organic $\mathrm{C}$ measured using an elemental CHNS analyser.

\subsection{Data analysis}

Physical and chemical data were compared between the three farms, and between three site groupings on each farm by two-way mixed model analysis of variance (ANOVA), with farm being a random factor and site a fixed factor. The site groupings consisted of sites outside the farm, sites at the boundary, and sites within the farm. Each site along a transect was a replicate for one of these groupings. Normality of the data and homogeneity of variances were examined from box plots, and some variables were transformed to normalise the data. If significant differences were detected, then multiple comparisons were conducted using Tukey's test (Day and Quinn, 1989).

Benthic invertebrate community data were analysed using both univariate and multivariate statistical analyses. Univariate indices examined were species richness measured as total number of species, total abundance, and the Shannon diversity index. Means were compared by ANOVA as for physical and chemical data.

Benthic species community data were compared by multivariate analyses using the PRIMER $^{\mathrm{TM}}$ software package. The species abundance data were square-root-transformed before analysis to reduce the contribution of rare species and a similarity matrix was constructed using the Bray-Curtis similarity index. Patterns in benthic infaunal assemblages at the sample sites were analysed using hierarchical agglomerative clustering and multidimensional scaling (MDS) ordination. Differences in species abundance between sites outside the farm, at the boundary and inside the farm were tested using analysis of similarity (ANOSIM). Relative contributions of each species to the average similarities of these groupings were calculated using SIMPER analysis. These results were then used to determine if any particular species were indicative of the patterns identified by cluster and ordination analyses.

\section{Results}

\subsection{Sediment particle size}

The sediment at St. Helens was extremely fine and all sample sites had at least 98\% silts and clays. Sediments at the Port Esperance farm were predominately fine sand and silts and clays, although there was considerable variation between sites along each transect (Fig. 4). At Eaglehawk Bay the sediment particle size was highly variable within the lease (Fig. 4). Sites along transect 1 contained sediments with relatively high levels of shell fragments and predominately medium sands. High 


\section{Port Esperance}
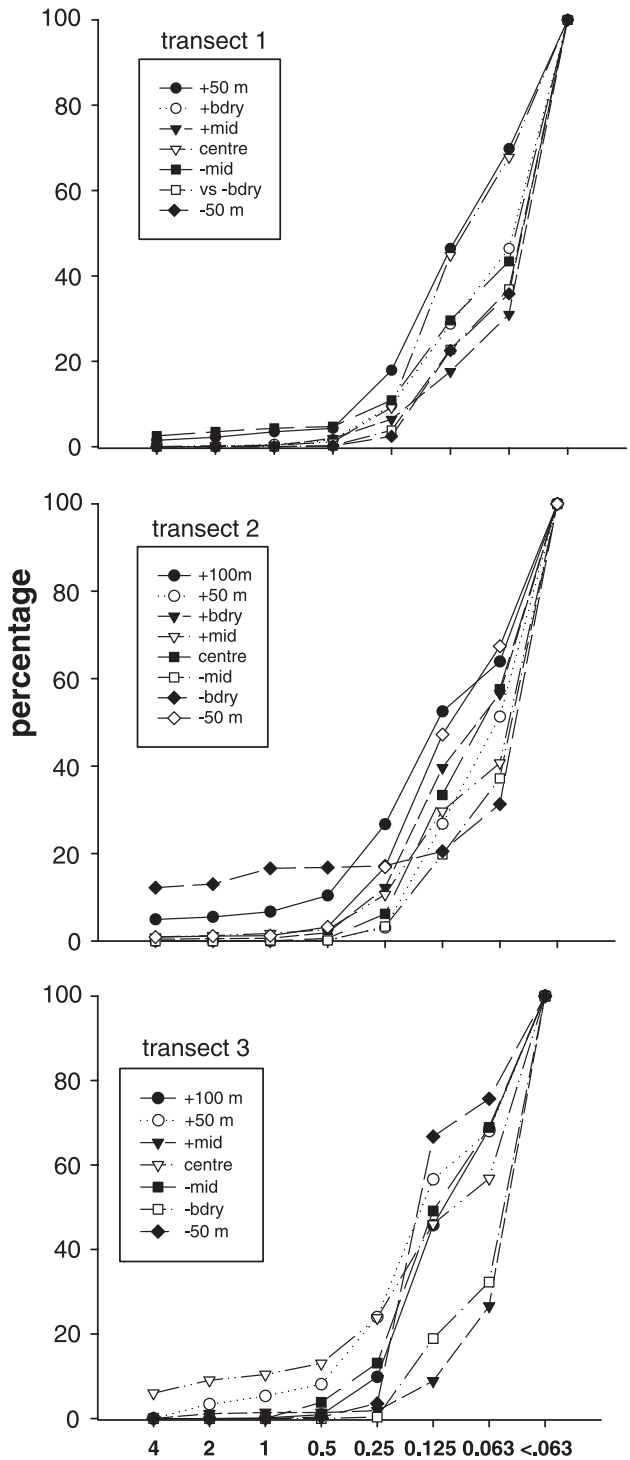

Eaglehawk Bay
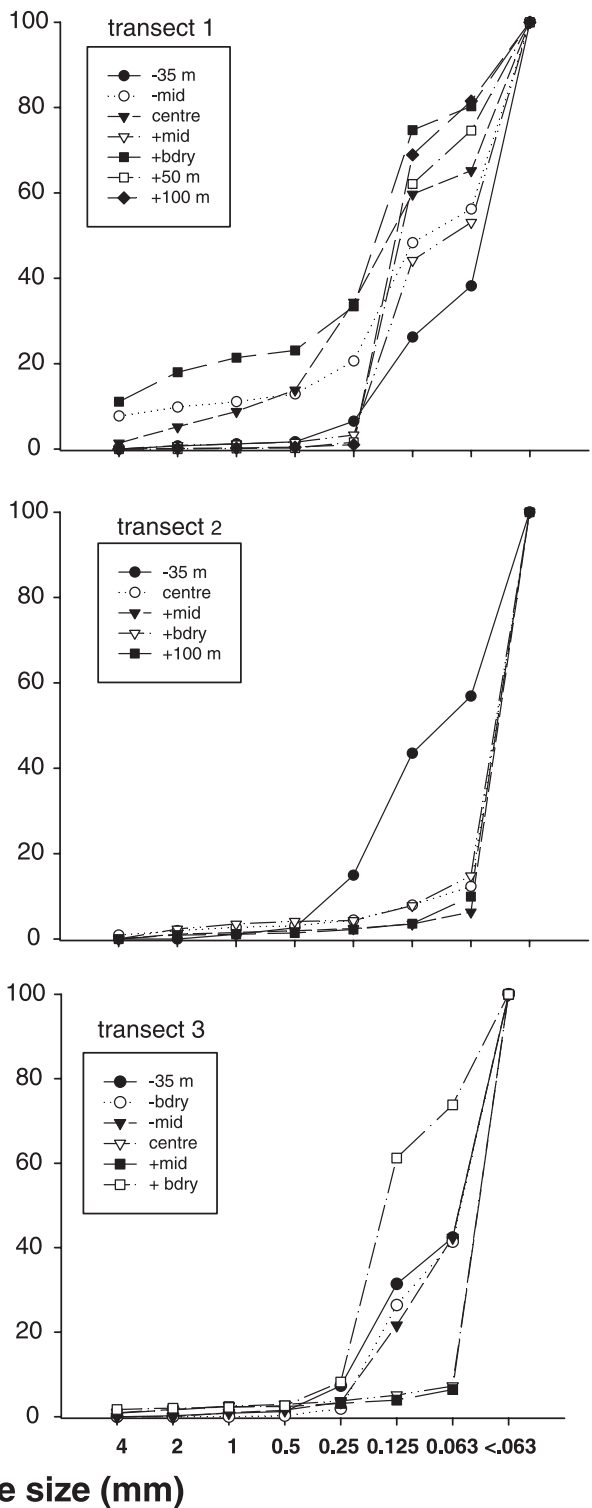

Fig. 4. Sediment particle size at Port Esperance and Eaglehawk Bay.

percentages of silts and clays $(>84 \%)$ were found in most sediment samples along transect 2, except for the site outside the western boundary. The eastern end of transect 3 was composed of mostly medium sand, whereas sites on the western side of 
the farm had around $58 \%$ silts and clays, rising to $>92 \%$ at sites in deeper water around the centre of the transect.

\subsection{Sediment deposition}

The rate of deposition of sediment in the sediment traps was significantly different between farms and was much lower at Port Esperance (average $7.2 \mathrm{~g} \mathrm{~m}^{2}$ day $^{-1}$ ) than at the other two sites (Fig. 5; Table 1). Deposition of sediment in the traps inside and outside the farm area varied between the three farms. At Port Esperance and St. Helens both highest and lowest deposition rates occurred at reference sites outside the farm, whereas at Eaglehawk Bay both farm sites had higher rates of sediment deposition $\left(14.5 \mathrm{~g} \mathrm{~m}^{2}\right.$ day $\left.^{-1}\right)$ than reference sites. ANOVA indicated that overall the rate of deposition of sediment was not significantly different between sites inside and outside the farms (Table 1).

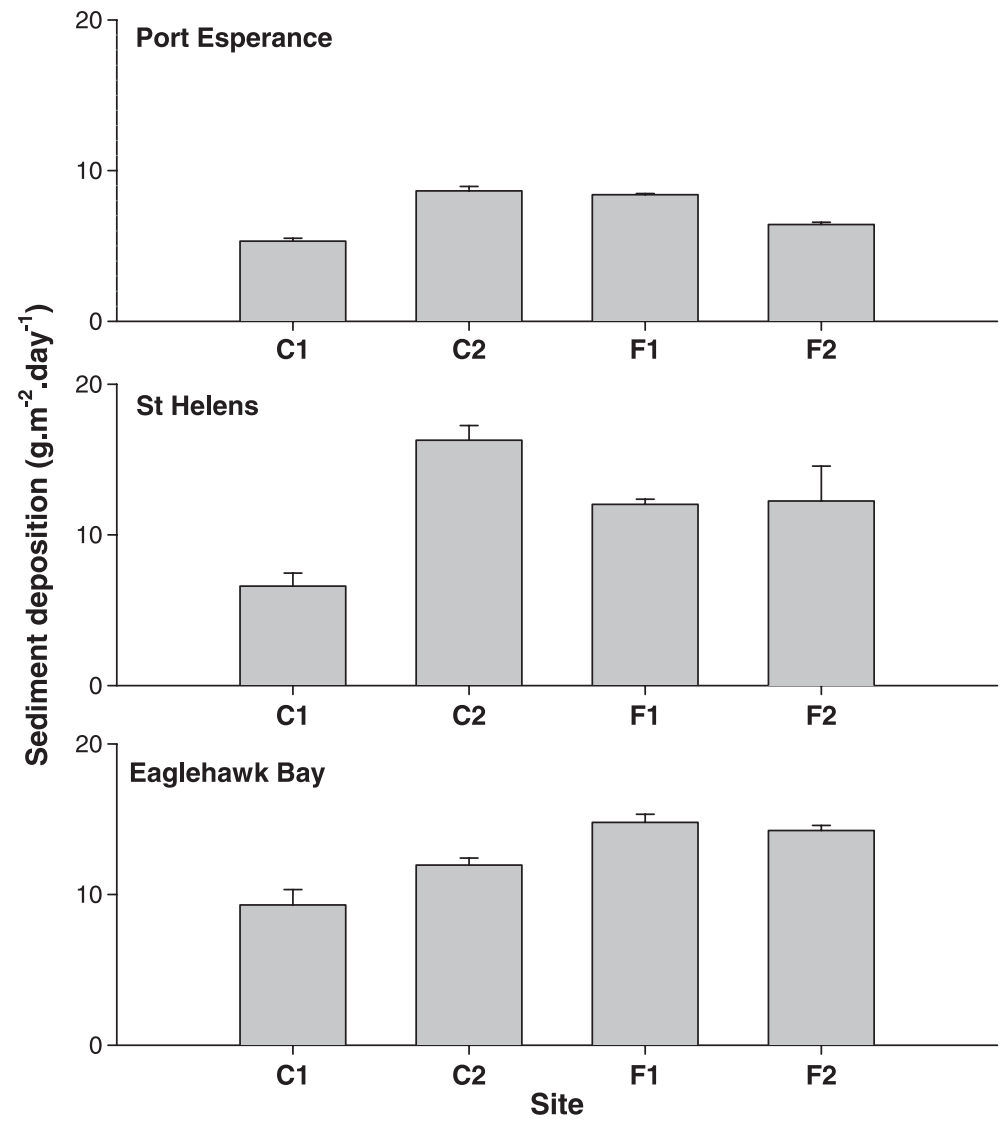

Fig. 5. Rate of sediment deposition at the three farm locations (means \pm S.E.). $F=$ site within the farm and $C=$ site outside the farm. 
Table 1

Results of mixed model two-way analysis of variance of environmental data at three shellfish farms and at three site groupings (outside, boundary and within farm lease area) around each farm

\begin{tabular}{|c|c|c|c|c|c|c|}
\hline Variable & $\begin{array}{l}\text { Source of } \\
\text { variability }\end{array}$ & $d f$ & Mean squares & $F$ & $P$ & $\begin{array}{l}\text { Tukey post hoc } \\
\text { test }\end{array}$ \\
\hline \multirow[t]{4}{*}{ Sediment deposition } & farm & 2 & 0.069 & 10.604 & $<0.001$ & PE $\underline{\mathrm{SH} E H}$ \\
\hline & site & 1 & 0.003 & 3.000 & ns & \\
\hline & farm $\times$ site & 2 & 0.001 & 0.087 & ns & \\
\hline & error & 29 & 0.007 & & & \\
\hline \multirow[t]{4}{*}{ Redox $1 \mathrm{~cm}$} & farm & 1 & 70094.570 & 29.949 & $<0.001$ & PE SH \\
\hline & site & 2 & 607.456 & 0.213 & ns & \\
\hline & farm $\times$ site & 2 & 2850.051 & 1.218 & ns & \\
\hline & error & 93 & 2340.476 & & & \\
\hline \multirow[t]{4}{*}{ Redox $4 \mathrm{~cm}$} & farm & 1 & 503099.961 & 120.898 & $<0.001$ & PE SH \\
\hline & site & 2 & 1283.765 & 0.193 & ns & \\
\hline & farm $\times$ site & 2 & 6648.731 & 1.598 & ns & \\
\hline & error & 93 & 4161.369 & & & \\
\hline \multirow[t]{4}{*}{ Sulphides $1 \mathrm{~cm}$} & farm & 2 & 39994.684 & 6.053 & $<0.01$ & EH SH PE \\
\hline & site & 2 & 16544.294 & 3.193 & ns & \\
\hline & farm $\times$ site & 4 & 12527.612 & 1.896 & ns & \\
\hline & error & 64 & 6607.943 & & & \\
\hline \multirow[t]{4}{*}{ Sulphides $4 \mathrm{~cm}$} & farm & 2 & 171549.051 & 7.752 & $<0.01$ & EH SH PE \\
\hline & site & 2 & 25557.178 & 1.123 & $\mathrm{~ns}$ & \\
\hline & farm $\times$ site & 4 & 22749.594 & 1.028 & ns & \\
\hline & error & 63 & 22130.099 & & & \\
\hline \multirow[t]{4}{*}{ Organic carbon } & farm & 2 & 72.484 & 105.141 & $<0.001$ & PE EH SH \\
\hline & site & 2 & 2.143 & 2.283 & ns & \\
\hline & farm $\times$ site & 4 & 0.758 & 1.100 & ns & \\
\hline & error & 136 & 0.689 & & & \\
\hline \multirow[t]{4}{*}{ Turbidity } & farm & 1 & 23.274 & 54.568 & $<0.001$ & PE SH \\
\hline & site & 2 & 0.005 & 0.044 & ns & \\
\hline & farm $\times$ site & 2 & 0.115 & 0.269 & ns & \\
\hline & error & 43 & 0.427 & & & \\
\hline
\end{tabular}

Farms are random and site groupings are fixed factors. $P>0.05=\mathrm{ns}$. $\mathrm{PE}=$ Port Esperance, $\mathrm{SH}=$ St. Helens and $\mathrm{EH}=$ Eaglehawk Bay. In Tukeys post hoc test, sites that are not significantly different are underscored.

\subsection{Redox}

Redox values did not drop below zero at any sites. At Port Esperance values at $1 \mathrm{~cm}$ depth were within the range of $300-400 \mathrm{mV}$, and at $4 \mathrm{~cm}$ depth were around $200 \mathrm{mV}$, with no obvious differences between inside and outside the lease boundary (Fig. 6). At St. Helens average values were routinely between 300 and $400 \mathrm{mV}$ across the transects. On the northern side of the farm closest to another shellfish farm, redox values were more varied because of lower values recorded at transect 3 than at the other transects. A reduced number of results are available from Eaglehawk Bay because of a broken probe. Only the results for the new probe are shown in Fig. 6, and these values were noticeably lower than at the other farms.

Because of the reduced number of readings at Eaglehawk Bay, only the data from St. Helens and Port Esperance were analysed by ANOVA. This analysis showed a highly significant difference between farms, but not between sites, and the interaction term was not significant (Table 1). 

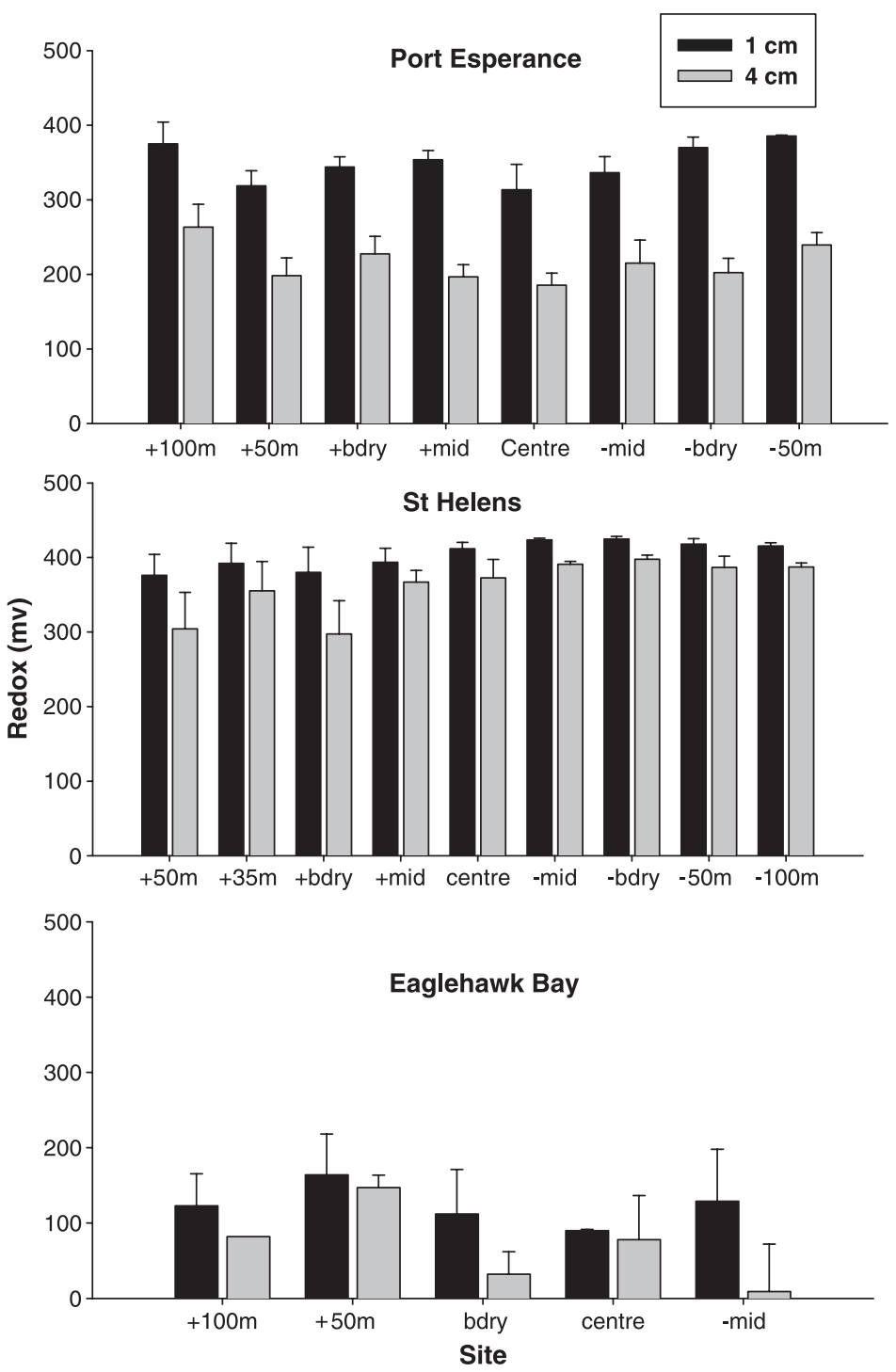

Fig. 6. Redox values $(\mathrm{mV})$ at the three farms (means \pm S.E.). Sample sites are shown from downstream $(+100 \mathrm{~m})$ to upstream $(-100 \mathrm{~m})$.

\subsection{Sulphide levels}

Sulphide concentrations were generally low at all sites, although they were significantly higher at Port Esperance than at the other farms (Fig. 7; Table 1). However, sulphide levels were not significantly different between sites located outside the farm, at the boundary and within the farm. At Port Esperance the differences between transects were more marked 


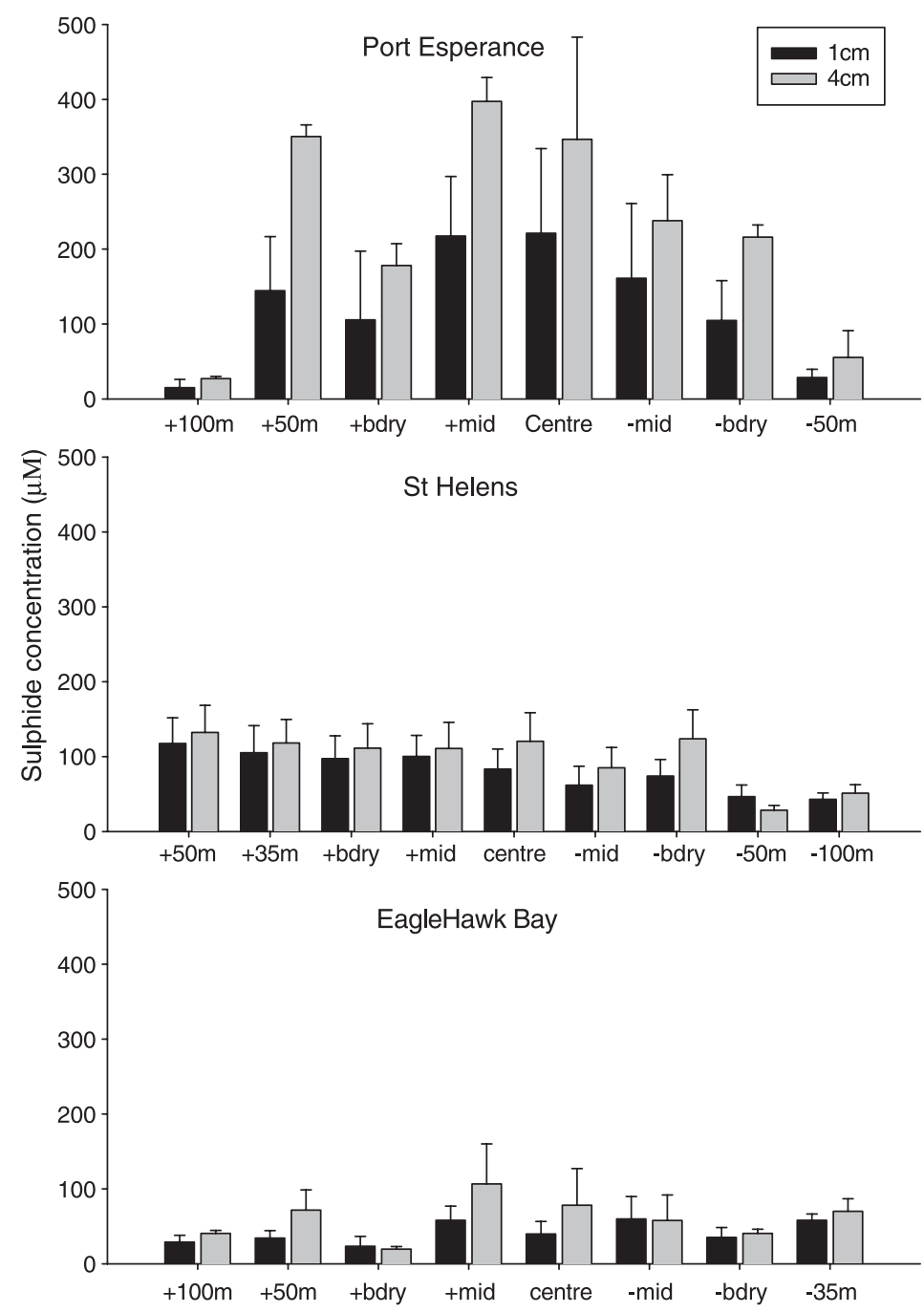

Fig. 7. Sulphide values at the three farms (means \pm S.E.). Sample sites are shown from downstream $(+100 \mathrm{~m})$ to upstream $(-100 \mathrm{~m})$.

than at the other farms, with transect 2 in the middle of the farm having the highest concentrations of up to $740 \mu \mathrm{M}$ (data not shown), and only at this transect were sulphide levels significantly higher within the farm and at the boundary than at sites outside the farms (one-way ANOVA, $P<0.05$ ).

\subsection{Organic carbon}

Percentage organic carbon was highest at St. Helens (3-4\%) where it varied little between inside and outside the farm (Fig. 8). However, slightly lower values and greater 

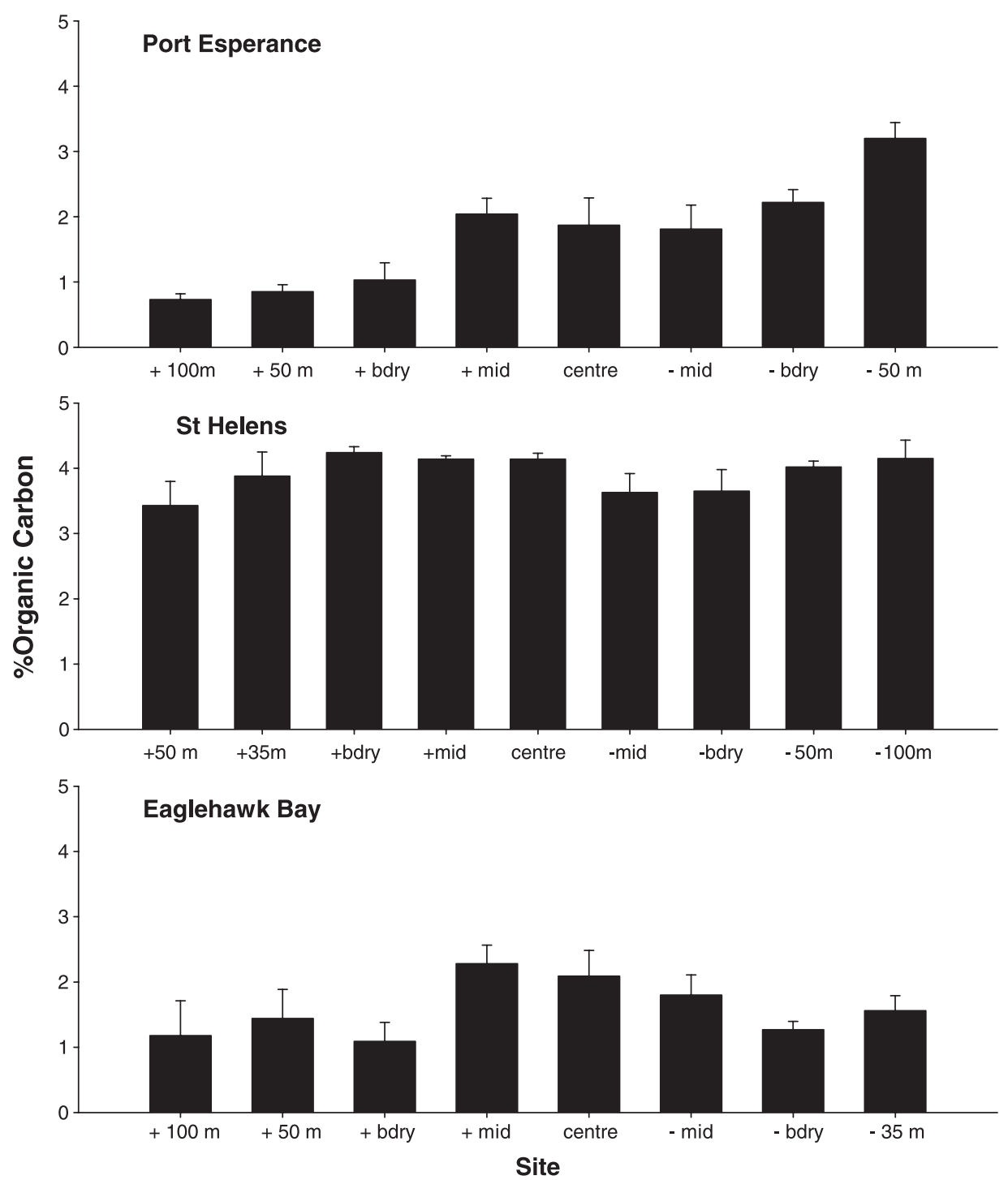

Fig. 8. Percentage organic carbon at the three farms (means \pm S.E.). Sample sites are shown from downstream $(+100 \mathrm{~m})$ to upstream $(-100 \mathrm{~m})$.

variation was found at sites on transect 3 nearest the adjacent marine farm. At Port Esperance organic $\mathrm{C}$ content was lower, and tended to increase upstream. The \% organic carbon at Eaglehawk Bay was more variable and in the range of $1.2-2.3 \%$, with slightly higher values within the farm, especially along transect 3 (Fig. 8). ANOVA showed that \% organic $\mathrm{C}$ was significantly higher at St. Helens than at the other farms, and that no significant trends were apparent along the transects (Table 1). 


\subsection{Turbidity}

Turbidity levels at Port Esperance varied across the transects and were highest at the downstream boundary and $50 \mathrm{~m}$ beyond, but were lowest at $100 \mathrm{~m}$ (Fig. 9). At St. Helens turbidity was significantly higher, and values were more uniform across the transects (Fig. 9). No significant differences were found between sites located inside, at the boundary and outside the farms (Table 1). Turbidity was not recorded at Eaglehawk Bay.

\subsection{Video recordings}

Because of the high concentration of suspended particles in the water column at St. Helens, the quality of the video footage from this site was too poor to be able to reliably distinguish characteristic features of the seabed.

At Port Esperance video footage under the farm generally showed fine sediment with high densities of small burrows and conspicuous faunal tracks. Algal cover was mostly sparse red/browns. The introduced gastropod Maoricolpus roseus occurred in low densities, and several specimens of the fish Platycephalus bassensis were observed. Black

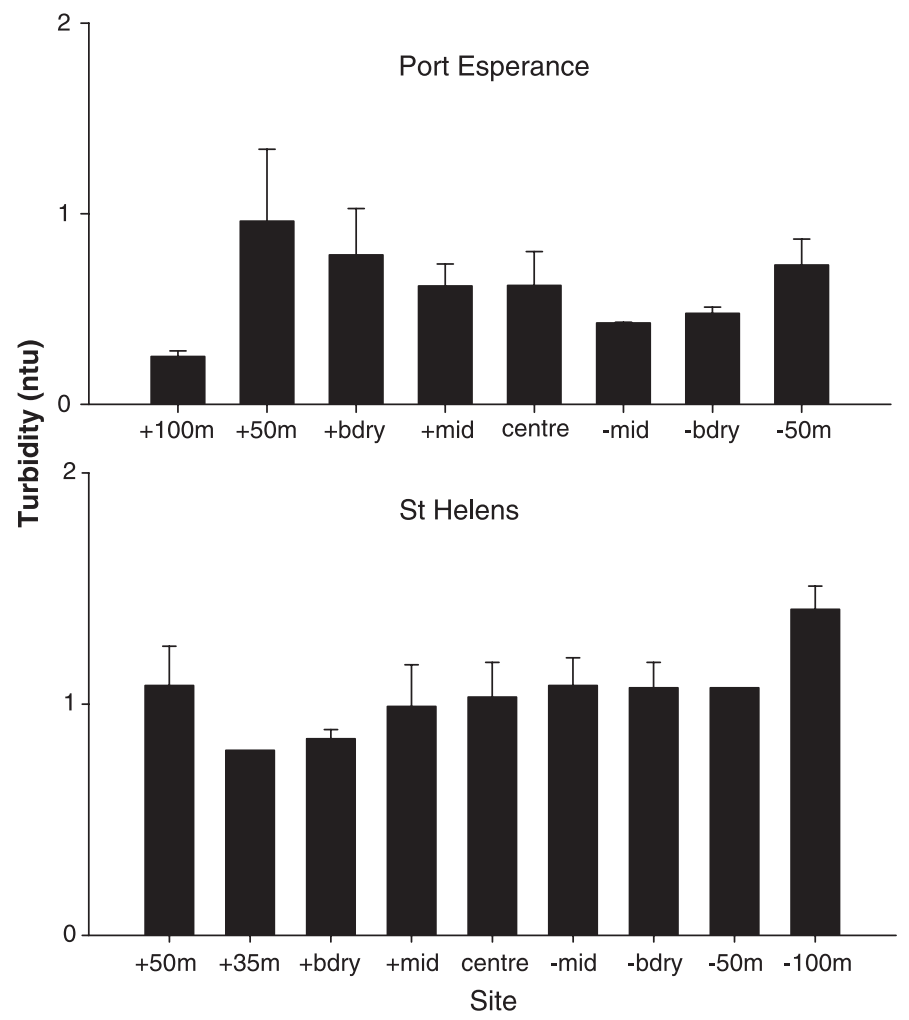

Fig. 9. Turbidity levels at Port Esperance and St. Helens. Sample sites are shown from downstream $(+100 \mathrm{~m})$ to upstream $(-100 \mathrm{~m})$. 
sediment indicative of anoxic conditions and patchy bacterial mats (Beggiatoa sp.) were observed over approximately $30 \mathrm{~m}$ of one farm transect (V3) and at approximately $30 \mathrm{~m}$ inside the farm of the upstream video transect (V4, see Fig. 1). Dense coverage of fine filamentous algae was also present at these sites. This algae was decomposing and appeared to have originally been attached to the longlines, but had sloughed off the lines onto the seabed. Neither deposits of fine filamentous algae nor anoxic sediments were observed outside the farm. There was little noticeable difference along the transects

Table 2

Univariate indices of macrofaunal community structure - mean number of species per core, mean number of individuals per core, and mean Shannon index per core

\begin{tabular}{|c|c|c|c|c|c|c|c|}
\hline Site & $n$ & $\begin{array}{l}\text { Species } \\
\text { number }\end{array}$ & S.E. & $\begin{array}{l}\text { No. of } \\
\text { individuals }\end{array}$ & S.E. & $\begin{array}{l}\text { Shannon } \\
\text { index }\end{array}$ & S.E. \\
\hline \multicolumn{8}{|c|}{ Eaglehawk Bay } \\
\hline $\mathrm{T} 1-35 \mathrm{~m}$ & 6 & 6.3 & 0.7 & 17.2 & 2.7 & 1.6 & 0.1 \\
\hline T2 - bdry & 4 & 5.2 & 1.7 & 21.5 & 9.5 & 0.9 & 0.3 \\
\hline $\mathrm{T} 3$ - mid & 6 & 7.6 & 0.8 & 17.8 & 3.1 & 1.8 & 0.1 \\
\hline T4 centre & 6 & 7.8 & 1.3 & 20.8 & 5.9 & 1.6 & 0.2 \\
\hline $\mathrm{T} 5+\mathrm{mid}$ & 6 & 7.1 & 1.6 & 15.8 & 4.2 & 1.5 & 0.3 \\
\hline T6 + bdry & 6 & 10.6 & 2.4 & 34.5 & 10.6 & 1.8 & 0.4 \\
\hline $\mathrm{T} 7+50 \mathrm{~m}$ & 6 & 7.8 & 1.2 & 30.5 & 10.7 & 1.4 & 0.1 \\
\hline $\mathrm{T} 8+100 \mathrm{~m}$ & 6 & 9.5 & 1.3 & 41.8 & 11.5 & 1.5 & 0.2 \\
\hline Mean & & 8.0 & 3.6 & 25.2 & 19.8 & 1.5 & 0.6 \\
\hline Total species & & 81 & & & & & \\
\hline \multicolumn{8}{|c|}{ Port Esperance } \\
\hline $\mathrm{T} 1+100 \mathrm{~m}$ & 4 & 15.0 & 2.7 & 35.0 & 9.1 & 2.4 & 0.1 \\
\hline $\mathrm{T} 2+50 \mathrm{~m}$ & 4 & 8.5 & 1.9 & 12.0 & 2.8 & 1.9 & 0.3 \\
\hline T3 + bdry & 6 & 9.7 & 1.9 & 16.0 & 3.7 & 1.8 & 0.4 \\
\hline $\mathrm{T} 4+\mathrm{mid}$ & 6 & 10.5 & 1.3 & 18.8 & 4.1 & 2.2 & 0.1 \\
\hline T5 centre & 6 & 11.7 & 1.2 & 23.8 & 4.0 & 2.2 & 0.1 \\
\hline T6 - mid & 6 & 8.5 & 1.5 & 18.2 & 3.1 & 1.9 & 0.2 \\
\hline T7 - bdry & 5 & 8.8 & 2.2 & 15.6 & 4.5 & 1.8 & 0.3 \\
\hline $\mathrm{T} 8-50 \mathrm{~m}$ & 5 & 11.6 & 0.8 & 24.6 & 5.3 & 2.3 & 0.1 \\
\hline Mean & & 10.4 & 4.0 & 20.3 & 11.4 & 2.1 & 0.5 \\
\hline Total species & & 74 & & & & & \\
\hline \multicolumn{8}{|l|}{ St. Helens } \\
\hline $\mathrm{T} 1+50 \mathrm{~m}$ & 4 & 3.8 & 0.9 & 6.8 & 2.0 & 1.1 & 0.2 \\
\hline $\mathrm{T} 2+35 \mathrm{~m}$ & 6 & 4.5 & 0.7 & 10.8 & 1.6 & 1.3 & 0.2 \\
\hline T3 + bdry & 5 & 3.8 & 0.7 & 6.0 & 1.6 & 1.2 & 0.2 \\
\hline $\mathrm{T} 4+\mathrm{mid}$ & 5 & 6.0 & 1.0 & 13.6 & 2.8 & 1.5 & 0.1 \\
\hline T5 centre & 5 & 5.8 & 1.2 & 11.8 & 2.9 & 1.5 & 0.2 \\
\hline $\mathrm{T} 6-\mathrm{mid}$ & 3 & 2.3 & 0.9 & 3.0 & 1.5 & 0.7 & 0.4 \\
\hline T7 - bdry & 5 & 5.4 & 0.7 & 11.4 & 1.6 & 1.5 & 0.2 \\
\hline $\mathrm{T} 8-50 \mathrm{~m}$ & 3 & 8.3 & 2.4 & 14.3 & 6.4 & 1.8 & 0.2 \\
\hline $\mathrm{T} 9-100 \mathrm{~m}$ & 5 & 6.0 & 1.0 & 11.0 & 2.6 & 1.6 & 0.2 \\
\hline Mean & & 5.1 & 0.4 & 10.1 & 0.9 & 1.4 & 0.7 \\
\hline Total species & & 36 & & & & & \\
\hline
\end{tabular}

$n=$ number of cores; S.E. $=$ standard error. 
progressing from inside to outside the farm, except in the areas of dense algal cover inside the lease.

At Eaglehawk Bay seagrass occurred at high densities along video transects inside the farm and at the western boundary (V1-V3, see Fig. 3) and at slightly lower densities along the eastern boundary transect (V4). Within the farm in shallower water (V1) the dominant seagrass was Heterozostera tasmanica, with smaller quantities of Halophila australis. A dense bed of $H$. tasmanica was also filmed under trays of oysters. At slightly deeper water within the farm (V3) the dominant algae was Caulerpa trifaria. The western boundary transect, V2, consisted of mixed beds of $H$. australis and $H$. tasmanica. At the eastern boundary transect the concentration of suspended matter in the water column was high, and the vegetation cover consisted mainly of $C$. trifaria and the seagrass $H$. australis, with a little $H$. tasmanica. No signs of organic enrichment such as Beggiatoa were observed. Also, largely because of the dense vegetation, benthic invertebrate fauna were rarely seen. No changes in conditions along boundary transects from inside to outside the farm were obvious.

\subsection{Benthic infaunal composition}

Univariate measures of benthic infauna differed between the farms. Highest numbers of species were collected from Port Esperance and lowest from St. Helens (Table 2). St. Helens also recorded the lowest numbers of individuals per sample and was much lower than the other farms. Eaglehawk Bay had the greatest mean number of individuals per site but the highest sample variances were also recorded at this farm. Shannon diversity indices showed less variation both within and between the farms than either species number or number of individuals, although values were generally lower at St. Helens and Eaglehawk Bay than at Port Esperance. Two-way analysis of variance (farm, site) using the "a priori" site groupings of "outside the farm", " farm boundary" and "inside the farm" showed that for all of the univariate indices, there were highly significant differences between

Table 3

Mixed model two-way analysis of variance of univariate indices of benthic infaunal community structure at three farms and at site groupings of outside, boundary and inside the farms

\begin{tabular}{|c|c|c|c|c|c|c|}
\hline Variable & $\begin{array}{l}\text { Source of } \\
\text { variability }\end{array}$ & $d f$ & Mean square & $F$ & $P$ & $\begin{array}{l}\text { Tukey post } \\
\text { hoc test }\end{array}$ \\
\hline \multirow[t]{4}{*}{ No. of species } & farm & 2 & 55.039 & 12.029 & $<0.001$ & SH EH PE \\
\hline & site & 2 & 2.895 & 3.143 & ns & \\
\hline & farm $\times$ site & 4 & 0.921 & 0.201 & ns & \\
\hline & error & 15 & 4.575 & & & \\
\hline \multirow[t]{4}{*}{ No. of individuals } & farm & 2 & 507.921 & 9.583 & $<0.001$ & SH PE EH \\
\hline & site & 2 & 65.406 & 1.510 & ns & \\
\hline & farm $\times$ site & 4 & 43.304 & 0.817 & ns & \\
\hline & error & 15 & 53.002 & & & \\
\hline \multirow[t]{4}{*}{ Shannon index } & farm & 2 & 0.915 & 9.280 & $<0.001$ & $\underline{\text { SH PE EH }}$ \\
\hline & site & 2 & 0.071 & 1.821 & ns & \\
\hline & farm $\times$ site & 4 & 0.039 & 0.391 & ns & \\
\hline & error & 15 & 0.099 & & & \\
\hline
\end{tabular}


farms. However, differences between site groupings and farm $\times$ site interactions were not significant. (Table 3).

Multivariate analysis of the faunal data for Port Esperance showed that the site groupings (outside, boundary and inside the farm) were not significantly different (ANOSIM: $R=-0.031, P>0.05$ ). Cluster analysis of the community data also showed that generally the sites were similar. The sites split into two groups at a high overall similarity level of 53\% (Fig. 10) and the resultant groupings largely reflect the upstream (6, 7 and 8) and downstream sites (1,3, 4 and 5), with the exception of site 2 which clustered with the upstream sites. The benthic community at Port Esperance was relatively diverse, with a total of 74 species being identified (Table 2). Polychaetes comprised the greatest proportion of the fauna (45\%), but there were no obviously dominant species and changes between the groups/sample sites were largely as a result of small-scale changes in abundance and distribution (Table 4). A few species known to be capable of tolerating low levels of organic enrichment were present in low densities but the characteristic indicators of organic enrichment (e.g. Capitella capitata (spp. complex) were either absent or at very low levels.

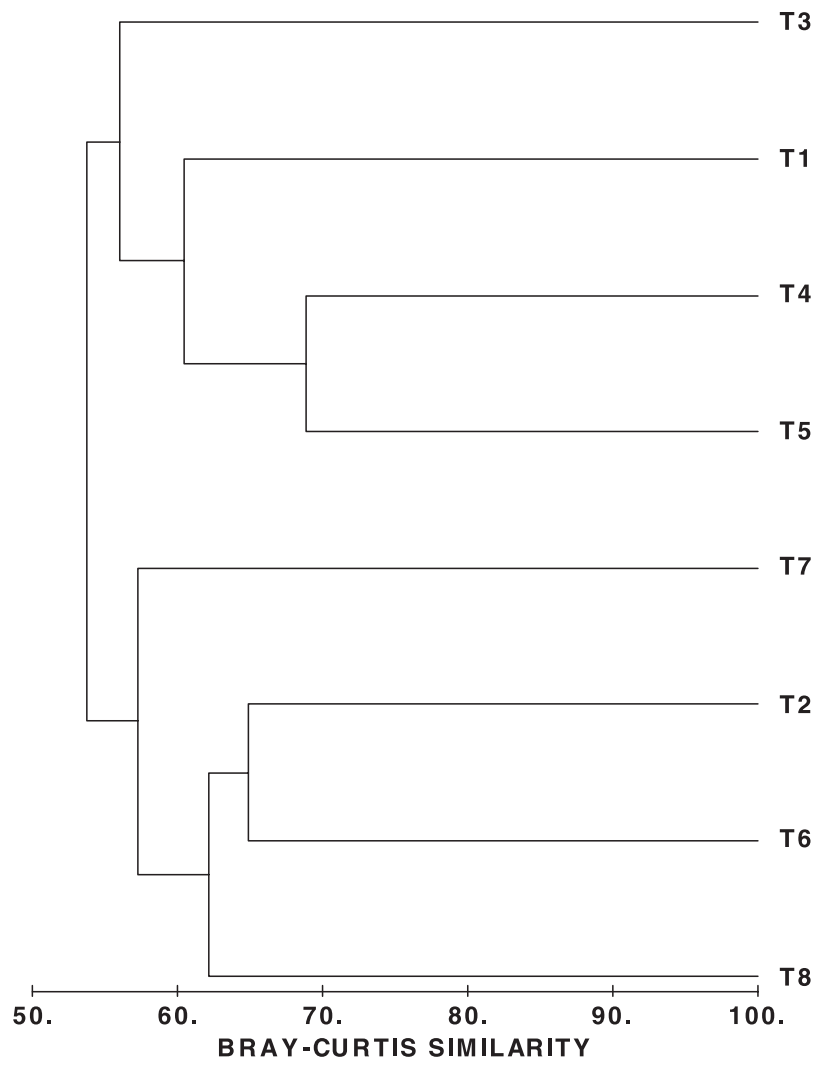

Fig. 10. Dendrogram for hierarchical clustering of eight sites at Port Esperance. Transects T1-T8 as labelled in Table 2. 
Table 4

SIMPER output indicating average abundance (number $\mathrm{m}^{-2}$ ) and $\%$ contribution to group classification (outside farm, boundary and inside farm) of the five most important species at each farm

\begin{tabular}{|c|c|c|}
\hline & No. $/ \mathrm{m}^{2}$ & $\%$ Contribution \\
\hline \multicolumn{3}{|l|}{ Port Esperance } \\
\hline \multicolumn{3}{|l|}{ Outside farm } \\
\hline Mediomastus australiensis & 213 & 24.71 \\
\hline Nemertea sp. 1 & 82 & 17.87 \\
\hline Nephtys australiensis & 61 & 7.63 \\
\hline Theora lubrica & 65 & 7.16 \\
\hline Lumbrinereis sp. (MoV 322) & 178 & 6.28 \\
\hline \multicolumn{3}{|l|}{ Boundary } \\
\hline Asychis sp. 1 (MoV 907) & 124 & 27.23 \\
\hline Mediomastus australiensis & 181 & 19.80 \\
\hline Nemertea sp. 1 & 56 & 16.23 \\
\hline Lysilla jennacubinae & 45 & 8.42 \\
\hline Asychis sp. 2 & 90 & 8.41 \\
\hline \multicolumn{3}{|l|}{ Inside farm } \\
\hline Mediomastus australiensis & 94 & 15.36 \\
\hline Lumbrinereis sp. (MoV 322) & 118 & 13.58 \\
\hline Nephtys australiensis & 75 & 11.82 \\
\hline Theora lubrica & 92 & 10.62 \\
\hline Nemertea sp. 1 & 40 & 8.78 \\
\hline \multicolumn{3}{|l|}{ Eaglehawk Bay } \\
\hline \multicolumn{3}{|l|}{ Outside farm } \\
\hline Theora lubrica & 364 & 30.50 \\
\hline Simplisetia amphidonta & 216 & 26.25 \\
\hline Mediomastus australiensis & 81 & 7.23 \\
\hline Corophium ascherusicum & 41 & 7.17 \\
\hline Nephtys australiensis & 47 & 4.37 \\
\hline \multicolumn{3}{|l|}{ Boundary } \\
\hline Theora lubrica & 514 & 38.93 \\
\hline Flabelligeridae sp. 1 & 164 & 20.74 \\
\hline Simplisetia amphidonta & 40 & 10.80 \\
\hline Nemertea sp. 1 & 73 & 5.75 \\
\hline Retusa cf. pelyx & 45 & 5.49 \\
\hline \multicolumn{3}{|l|}{ Inside farm } \\
\hline Theora lubrica & 345 & 32.85 \\
\hline Simplisetia amphidonta & 125 & 13.61 \\
\hline Flabelligeridae sp. 1 & 75 & 13.14 \\
\hline Nephtys australiensis & 44 & 11.07 \\
\hline Echinocardium cordatum & 32 & 5.35 \\
\hline \multicolumn{3}{|l|}{ St. Helens } \\
\hline \multicolumn{3}{|l|}{ Outside farm } \\
\hline Diplocirrus sp. (MoV 2626) & 129 & 28.67 \\
\hline Nemertea sp. 1 & 125 & 26.94 \\
\hline Nephtys australiensis & 50 & 16.80 \\
\hline Asychis sp. 2 & 97 & 13.41 \\
\hline Theora lubrica & 44 & 6.13 \\
\hline
\end{tabular}


Table 4 (continued)

\begin{tabular}{lcc}
\hline & No. $/ \mathrm{m}^{2}$ & \% Contribution \\
\hline Boundary & & 33.60 \\
Asychis sp. 2 & 68 & 25.15 \\
Nemertea sp. 1 & 79 & 16.11 \\
Diplocirrus sp. (MoV 2626) & 119 & 12.88 \\
Nephtys australiensis & 45 & 3.32 \\
Asychis sp. 1 (MoV 907) & 23 & 26.93 \\
Inside farm & & 21.16 \\
Diplocirrus sp. (MoV 2626) & 113 & 20.57 \\
Nephtys australiensis & 52 & 10.05 \\
Nemertea sp. 1 & 174 & 9.80 \\
Paraprionospio coora & 39 & 52 \\
Asychis sp. 2 & 52 & \\
\hline
\end{tabular}

Code in brackets after species names indicates Museum of Victoria species classification codes.

At St. Helens the benthic invertebrate fauna were generally similar between sites (Table 4). However, ANOSIM of the "a priori" groupings indicated significant differences between the groups, but at a low level $(R=0.084, P=0.046)$. Post hoc testing showed that the sites outside the farm were significantly different from the boundary sites but not from

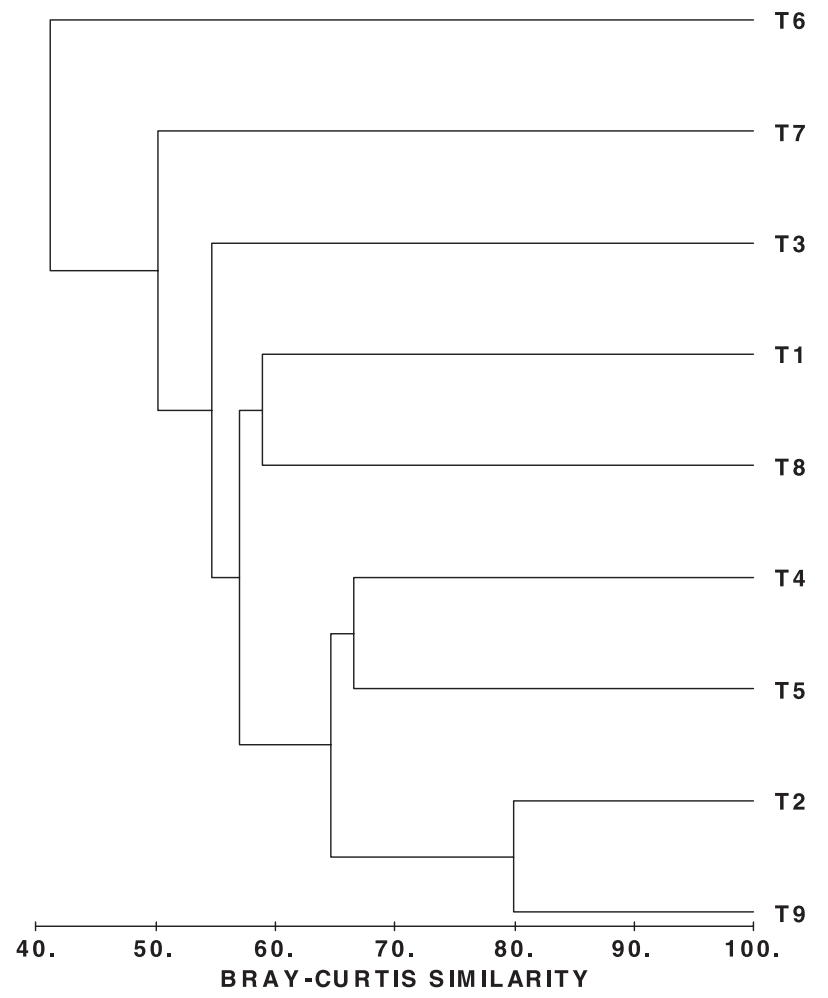

Fig. 11. Dendrogram for hierarchical clustering of nine sites at St. Helens. Transects T1-T9 as labelled in Table 2. 
the sites inside the farm. Cluster analysis suggested a progressive change between sites, particularly for the first three dichotomies (Fig. 11), suggesting that the differences were primarily as a result of minor changes in species abundances between sites. Site 6 separated from the others at a relatively high similarity level, approximately 40\% (Fig. 11). This site had the lowest diversity (lower number of species and individuals) (Table 2); replication was also low $(n=3)$ because of problems with sampling. Polychaete worms were again the most common group represented in the fauna, comprising $39 \%$ of all species recorded. Nemertean worms were also important: $19 \%$ of all individuals collected.

At Eaglehawk Bay ANOSIM analysis indicated significant differences between site groupings $(R=0.076, P=0.039)$, and the pairwise test showed that sites outside the farm were significantly different to those inside. Cluster analysis identified that site 1 was different from all others (Fig. 12). The dominant species at this site included some opportunists and species tolerant of both low oxygen and increased organic matter levels. C. capitata (spp. complex) was clearly the species responsible for the site separation (SIMPER analysis), and was only recorded at site 1, albeit in relatively low numbers. Simplisetia amphidonta, a Nereid polychaete, which is also relatively tolerant of increases in organic matter, was present at most Eaglehawk Bay sites, but generally at higher

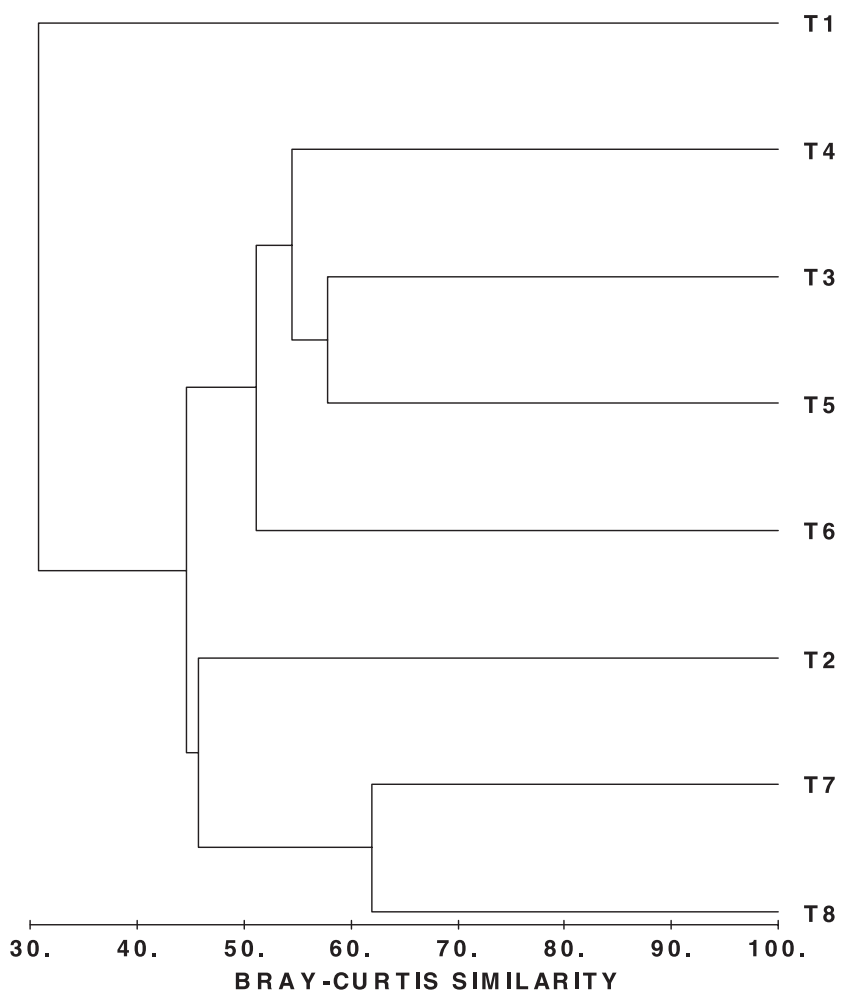

Fig. 12. Dendrogram for hierarchical clustering of nine sites at Eaglehawk Bay. Transects T1-T8 as labelled in Table 2. 
densities at the inshore shallower sites and particularly at site 1 (Table 4). This pattern of species distribution is opposite to that predicted because the species indicative of organic enrichment were found at the highest densities outside the farm, instead of in areas of intense culture. It is also noteworthy that the introduced bivalve mollusc, Theora lubrica, was by far the most common species at this farm, comprising $21 \%$ of all the individuals recorded.

\section{Discussion}

The results suggest that the effects of shellfish farming activities on the benthic environment under and near subtidal shellfish farms were low, and far less than results obtained from similar research conducted around salmon farms in Tasmania (Crawford et al., 2001, 2002). In contrast to conditions observed under some salmon farms, no extensive mats of Beggiatoa bacteria or spontaneous outgassing were observed, redox values did not drop below zero, and no major changes in benthic infauna to species tolerant of high organic loadings were found. Sulphide levels also were rarely above accepted background levels (Wildish et al., 1999). This is not surprising because no external food resources are required for shellfish production. Lesser impacts in Tasmania than under some shellfish farms in other countries are also to be expected because of the relatively low stocking densities on Tasmanian shellfish farms.

The farms we chose to investigate were selected based on production levels over a number of years. However, these farms had environmental conditions that may be considered to be less than ideal for shellfish culture: current flows were generally low, sediments had high percentages of silts and clays, and water depths at St. Helens and Eaglehawk Bay were relatively shallow for longline culture. Thus impacts on the bottom would be expected to be even lower in areas of higher current flows and water depths in Tasmania.

The results from this study are similar to those obtained by Thorne (1998) who measured the effects of four Tasmanian intertidal Pacific oyster farms on the surrounding benthic infaunal community. Although his experimental design differed to ours, he also found a much greater difference in benthic community structure between farms than between sites within and outside farms. The oyster culture areas generally had a higher species diversity, and number of species and individuals than reference areas, features which may be considered to be indicative of mild organic enrichment (Pearson and Rosenberg, 1978). Percentage organic matter was also found by Thorne (1998) to be significantly different between sites inside and outside the farms. However, this was not observed in our study of subtidal farms.

Our results are similar to those described by Chamberlain et al. (2001) in southwest Ireland at their site 1, where there were minimal effects of longline mussel culture on the benthic fauna under the farm. In contrast, their second farm site had elevated levels of organic enrichment and reduced macrobenthic infaunal diversity. Although Chamberlain et al. (2001) proposed that the differences between their two sites was largely because of different current patterns, the currents were relatively low at both sites. It is more likely 
that the larger level of production over a longer period of time at site 2 had a significant influence on the impact observed.

Grant et al. (1995) investigated the impact of suspended mussel culture on benthic communities in Nova Scotia, Canada, using a number of techniques, and also concluded that the impact overall was minor. However, the culture density of mussels in that study, approximately $12 \mathrm{~kg} \mathrm{~m}^{-2}$, was higher than that generally used in Tasmania, and the overall effects of mussel culture were also more obvious than in Tasmania. For example, the rate of sediment deposition was 2.4 times higher under mussel lines than at an adjacent reference site, and in summer Beggiatoa bacterial films were visible at the sediment surface under the mussels. However, the benthic invertebrate community did not clearly show the same effects of organic enrichment that have been observed in other studies, for example, under salmon farms. Grant et al. (1995) concluded that the impact on the benthic community structure was more noticeable from mussels fallen onto the seabed than from organic sedimentation or hypoxia.

The rates of sedimentation recorded in this study are much lower than those recorded by Grant et al. (1995) (annual average of $88.9 \mathrm{~g} \mathrm{~m}^{-2}$ day ${ }^{-1}$ ). They are, however, similar to measures obtained by Hayakawa et al. (2001) under Pacific oyster longline culture in Japan (annual mean of $11 \mathrm{~g} \mathrm{~m}^{-2}$ day $^{-1}$ ). This is surprising given that the density of oysters under culture was much greater in Japan, averaging 1100 individuals $\mathrm{m}^{-2}$. Both Grant et al. (1995) and Hayakawa et al. (2001) recorded much higher rates of sedimentation in the late summer-autumn period than at other times of the year. Similarly, Mitchell (2001) measured a four to five times higher rate of deposition of biodeposits directly under intertidal baskets of Pacific oysters at Pipe Clay Lagoon, Tasmania, in summer than in winter. As our results from the three farms were recorded in mid-late summer, maximum rates may not have been reached.

The analysis of benthic invertebrate communities shows that the infauna at St. Helens was more depauperate than at the other farms, both in number of species and total abundances. Although the sediment at this farm had higher organic content than the other farms, other measures of organic enrichment did not indicate impact around the farm. Redox values were high, sulphide levels were low, and species indicative of heavy organic loadings were not found. The sediment at St. Helens was almost entirely silts and clays, and this is the most likely factor influencing the reduced species richness and abundance.

Shallow inshore sites along transect 1 at Eaglehawk Bay were the only sites where species tolerant of low oxygen and increased organic enrichment were observed, in particular C. capitata (spp. complex), although in relatively low numbers compared with under salmon farms. This change in community composition may have occurred because shellfish biodeposits were washed inshore and concentrated in shallow water. However, it is also possible that dead seagrass and other organic debris external from the farm accumulated and decomposed in the shallows, resulting in anoxic conditions. Further assessments in shallow water would be necessary to clarify the source of the organic matter. However, at Port Esperance, macroalgae had clearly accumulated under the longlines, and this was the same algae that was growing on the mussel lines. These beds of decomposing seaweed were sufficiently large to render the sediment anoxic and result in patchy Beggiatoa mats. Thus, similar to the study of Grant et al. (1995) in Canada, it 
appears that the main effect of shellfish farms on the seabed is from the accumulation of waste mussels and attached algae rather than from the deposition of mussel faeces and pseudofaeces. Such waste material should not be allowed to accumulate outside the lease area as it may produce an unacceptable impact.

Of the physical environmental variables potentially suited to an aquaculture environmental monitoring program, we have previously recommended (Crawford et al., in press) redox as a quick and inexpensive gross measure of organic enrichment. However, the problems we encountered at Eaglehawk Bay indicate that the measurement of redox may not be as easy and reliable for routine monitoring as had been assumed. The results between the different probes in this study suggest that the ability of probes to record low values deteriorates with use and it is not currently possible to identify the presence or extent of this drift at the time. Unfortunately there is no standard solution for calibration at low values, and although we have previously observed differences in readings between probes, we were not aware of the subtle deterioration that was occurring. Consequently, it would appear appropriate, even with average usage, to replace redox probes at least annually, and to regularly check values between probes.

In summary, the results indicate that shellfish farming is having minimal effect on the benthic environment. This, in turn, suggests that extensive monitoring of shellfish farming is not necessary, and that simple measures such as photographic records of the farms collected every 1 or 2 years would be sufficient to address community concerns over negative impacts occurring as a result of shellfish farming activities.

\section{References}

Baudinet, D., Alliot, E., Berland, B., Grenz, C., Plante-Cuny, M., Plante, R., Salen-Picard, C., 1990. Incidence of mussel culture on biogeochemical fluxes at the sediment-water interface. Hydrobiologia 207, 187-196.

Buschmann, A.H., Lopez, D.A., Medina, A., 1996. A review of environmental effects and alternative production strategies of marine aquaculture in Chile. Aquacultural Engineering 15, 397-421.

Chamberlain, J., Fernandes, T.F., Read, P., Nickell, T.D., Davies, I.M., 2001. Impacts of biodeposits from suspended mussel (Mytilus edulis L.) culture on the surrounding surficial sediments. ICES Journal of Marine Science 58, 411-416.

Crawford, C.M., Mitchell, I.M., Macleod, C.K.A., 2001. Video assessment of environmental impacts of salmon farms. ICES Journal of Marine Science 58, 445-452.

Crawford, C., Macleod, C., Mitchell, I., 2002. Evaluation of techniques for environmental monitoring of salmon farms in Tasmania. Tasmanian Aquaculture and Fisheries Institute Technical Report Series 8.

Crawford, C.M., Mitchell, I.M., Macleod, C.K., in press. An assessment of the suitability of physical/chemical environmental variables to monitor organic enrichment from Atlantic salmon farms in Tasmania, Australia. Journal of Applied Ichthyology.

Dahlbäck, B., Gunnarsson, L.Å.H., 1981. Sedimentation and sulfate reduction under mussel culture. Marine Biology 63, 269-275.

Day, R.W., Quinn, G.P., 1989. Comparisons of treatments after an analysis of variance in ecology. Ecological Monographs 59, 433-463.

DPIF, 1996. Marine Farming Development Plans for Tasmania, Tasman Peninsular and Norfolk Bay. Tasmanian Department of Primary Industry and Fisheries, Hobart, p. 85.

DPIWE, 1998. Marine Farming Development Plans, Georges Bay. Tasmanian Department of Primary Industries, Water and Environment, Hobart, p. 140.

DPIWE, 1999a. Tasmanian Rural and Fishing Industry Profiles. Tasmanian Department of Primary Industries, Water and Environment, Hobart, p. 140. 
DPIWE, 1999b. Tasmanian Industry Audits-A Shared Vision. Department of Primary Industries, Water and Environment, Hobart, Tasmania.

Grant, J., Hatcher, A., Scott, D.B., Pocklington, P., Schafer, C.T., Winters, G.V., 1995. A multidisciplinary approach to evaluating impacts of shellfish aquaculture on benthic communities. Estuaries 18, 124-144.

Hayakawa, Y., Kobayashi, M., Izawa, M., 2001. Sedimentation flux from mariculture of oyster (Crassostrea gigas) in Ofunato estuary, Japan. ICES Journal of Marine Science 58, 435-444.

Kaiser, M.J., 2000. Ecological effects of shellfish cultivation. In: Black, K.D. (Ed.), Environmental Impacts of Aquaculture. Sheffield Academic Press, Sheffield, UK, pp. 51-75.

Kaiser, M.J., Laing, I., Utting, S.D., Burnell, G.M., 1998. Environmental impacts of bivalve mariculture. Journal of Shellfish Research 17, 59-66.

Mitchell, I.M., 2001. Relationship between water quality parameters (nutrients, seston, chlorophyll a), hydrodynamics and oyster growth in three major Pacific oyster (Crassostrea gigas) growing areas in southern Tasmani (Australia). Separtment of Agricultural Science. University of Tasmania, Hobart.

Pearson, T.H., Rosenberg, R., 1978. Macrobenthic succession in relation to organic enrichment and pollution of the marine environment. Oceanography and Marine Biology: An Annual Review 16, 229-231.

Tenore, K.R., Boyer, L.F., Cal, R.M., Corral, J., Garcia-Fernandez, C., Gonzalez, N., Gonzalez-Gurriaran, E., Hanson, R.B., Iglesias, J., Krom, M., Lopez-Jamar, E., McClain, J., Pamatmat, M.M., Perez, A., Rhoads, D.C., de Santiago, G., Tietjen, J., Westrich, J., Windom, H.L., 1982. Coastal upwelling in the Rias Bajas, NW Spain: contrating the benthic regimes of the Rias de Arosa and de Muros. Journal of Marine Research 40, $701-772$.

Thomson, J.M., 1952. The accilimatization and growth of the Pacific oyster (Gryphaea gigas) in Tasmania. Australian Journal of Marine and Freshwater Research 3, 64-73.

Thorne, A.J., 1998. Alterations in the structure of macrobenthic communities related to the culture of oysters (Crassostrea gigas). Zoology. University of Tasmania, Hobart, p. 102.

Wildish, D.J., Akagi, H.M., Hamilton, N., Hargrave, B.T., 1999. A recommended method for monitoring sediments to detect organic enrichment from mariculture in the Bay of Fundy. Canadian Technical Report of Fisheries and Aquatic Sciences 2286, 1-31. 